\title{
PROFIL PENDERITA HIPERTENSI DI RSUD JOMBANG PERIODE JANUARI-DESEMBER 2011
}

\author{
Bagus Ramanto Saputra ${ }^{1}$, Rahayu $^{2}$, Iwan Sis Indrawanto ${ }^{3}$
}

\author{
Fakultas Kedokteran Universitas Muhammadiyah Malang, J1. Bendungan Sutami No. 188A, Kota Malang, \\ 65145, Indonesia 0341-551149
}

Email bagusramanto@gmail.com

\begin{abstract}
Abstrak
Profil Penderita Hipertensi di RSUD Jombang Periode Januari-Desember 2011. Latar Belakang. Hipertensi atau tekanan darah tinggi merupakan pembunuh diam-diam karena pada sebagian besar kasus tidak menunjukkan gejala apapun. Hipertensi merupakan salah satu faktor resiko utama yang menyebabkan serangan jantung dan stroke, yang menyerang sebagian besar penduduk dunia. Prevalensi hipertensi di negara-negara maju cukup tinggi, yaitu mencapai 37\%. Sementara di negara-negara berkembang 29,9\%. Tujuan. Mengetahui profil penderita Hipertensi di RSUD Jombang Periode Januari - Desember 2011. Metode Penelitian. Deskriptif observasional, dengan rancangan penelitian studi kasus dan tehnik pengambilan sampel menggunakan total sampling. Sampel penelitian ini yaitu 337 orang. Hasil dan Kesimpulan. Dari 337 orang penderita hipertensi, jumlah terbanyak berumur? 61 tahun (38,5\%), berjenis kelamin perempuan (52,6\%), tingkat pendidikan SD (47,2\%), pekerjaan ibu rumah tangga (37,1\%), keluhan utama sesak napas $(29,9 \%)$, hipertensi primer $(96,2 \%)$, hipertensi derajat $2(53,8 \%)$, tidak ada riwayat penyakit hipertensi pada keluarganya $(75,6 \%)$.
\end{abstract}

\begin{abstract}
The Profile of Hypertension at RSUD Jombang in January to December 2011 Period. Introduction. Hypertension is a silent killer because in most cases did not show any symptoms. Hypertension is one of the major risk factors that cause heart attacks and stroke, affecting most of the world's population. The prevalence of bypertension in developed countries is quite high, which reached $37 \%$. While in developing countries 29.9\%. Objective : To know the profile of bypertension patients at RSUD Jombang in Januari to Desember 2011 Period. Method. Descriptive observational, with case study research design and using total sampling. This study sample were 337 people. Result and Conclusion. From 337 people, the greatest number of bypertension were patients aged? 61 years (38,5\%), the gender was female (52,6\%), the level of education was elementary school (47.2\%), the work were housewives (37,1\%), the main complaint was shortness of breath (29,9\%), primary bypertension (96,2\%), bypertension of degree 2 (53,8\%), and without any family bistory of bypertension (75.6\%).
\end{abstract}

Key words : hypertension.

\section{PENDAHULUAN}

Hipertensi atau tekanan darah tinggi merupakan pembunuh diam-diam karena pada sebagian besar kasus tidak menunjukkan gejala apapun. Hipertensi merupakan salah satu faktor resiko utama yang menyebabkan serangan jantung dan stroke, yang menyerang sebagian besar penduduk dunia. Hipertensi adalah suatu keadaan dimana dijumpai tekanan darah 140/90 mmHg atau lebih untuk usia 13 - 50 tahun dan tekanan darah mencapai $160 / 95 \mathrm{mmHg}$ untuk usia di atas 50 tahun. Pengukuran tekanan darah minimal sebanyak dua kali untuk lebih memastikan keadaan tersebut (WHO, 2005). Hipertensi dapat dikelompokan menjadi dua jenis, yaitu: Hipertensi primer atau essensial dan hipertensi sekunder. Hipertensi primer adalah hipertensi yang tidak atau belum diketahui penyebabnya. Hipertensi primer menyebabkan perubahan pada jantung dan pembuluh darah. Sedangkan hipertensi sekunder adalah hipertensi yang disebabkan atau sebagai akibat dari adanya penyakit lain dan biasanya penyebabnya sudah diketahui, seperti penyakit ginjal dan kelainan hormonal atau pemakaian obat tertentu (Anggraini, 2009).
Prevalensi hipertensi pada penderita perempuan lebih tinggi, yaitu 37\%, sedangkan pria 28\%. Prevalensi hipertensi di negara-negara maju cukup tinggi, yaitu mencapai 37\%. Sementara di negara-negara berkembang 29,9\% (WHO, 2005). Di Indonesia prevalensi hipertensi tahun 2007 mencapai $31,7 \%$ dari total jumlah penduduk dewasa, lebih tinggi jika dibandingkan dengan Singapura yang mencapai 27,3\%, Thailand dengan 22,7\% dan Malaysia mencapai 20\% (Riskesdas, 2007). Prevalensi di daerah Jawa dan Bali sedikit lebih tinggi dibandingkan dengan kawasan Sumatra dan kawasan Indonesia timur (SKRT, 2001). Menurut penelitian yang dilakukan oleh Ni Made Sarastini (2008) mengenai "Faktor-Faktor yang Berhubungan Dengan Kejadian Hipertensi pada Masyarakat Kelompok Usia 30 Tahun ke Atas di Kelurahan Grogol Kecamatan Limo Kodya Depok tahun 2008", dengan sampel 220 responden, didapatkan hasil yaitu sebanyak $37,3 \%$ responden mengalami stres, $70,5 \%$ responden mempunyai kebiasaan merokok, 1,4\% responden mempunyai kebiasaan mengkonsumsi alkohol, $75 \%$ responden mengkonsumsi makanan tinggi garam, 
dan 63,6\% responden mempunyai aktivitas fisik rendah.

Tujuan dari penelitian ini adalah untuk mengetahui profil penderita Hipertensi di RSUD Jombang periode Januari - Desember 2011. Selain itu tujuan lainnya adalah untuk mengetahui deskripsi penderita hipertensi berdasarkan usia, jenis kelamin, riwayat penyakit keluarga, tingkat pendidikan, jenis pekerjaan, keluhan utama, jenis hipertensinya, serta derajat hipertensinya.

Selain itu, manfaat dari penelitian ini adalah memberi informasi kepada tenaga medis tentang profil penderita hipertensi di RSUD Jombang, menjadi bahan acuan penyuluhan tenaga medis, sehingga diharapkan dapat menurunkan resiko hipertensi pada masyarakat, dan dapat dijadikan sebagai bahan atau sumber data untuk penelitian berikutnya.

Diharapkan pada penelitian ini dapat memberikan dampak yang positif kepada masyarakat, terutama di Jombang. Kemudian dapat menjadi sumber pengetahuan kepada masyarakat mengenai hipertensi sehingga dapat mengontrol tekanan darahnya dan melakukan pemeriksaan secara dini ke dokter. Dan pada akhirnya kualitas kesehatan di masyarakat menjadi baik.

\section{METODE}

Jenis penelitian yang digunakan adalah deskriptif observasional, dengan rancangan penelitian studi kasus. Populasi pada penelitian ini adalah semua penderita hipertensi di RSUD Jombang periode Januari - Desember 2011. Sedangkan untuk sampelnya adalah penderita hipertensi yang memenuhi kriteria inklusi dan eksklusi yang menjalani rawat inap di RSUD Jombang periode Januari - Desember 2011.

Adapun untuk kriteria inklusinya adalah penderita hipertensi yang sedang menjalani rawat inap di RSUD Jombang. Sedangkan untuk kriteria eksklusinya adalah penderita hipertensi yang sedang menjalani rawat jalan di RSUD Jombang. Tehnik pengambilan sampel pada penelitian ini menggunakan total sampling dan penelitian dilakukan di RSUD Jombang bulan Maret 2012.

Instrumen yang digunakan dalam penelitian ini adalah data sekunder dari rekam medis penderita hipertensi yang menjalani rawat inap di RSUD Jombang periode Januari Desember 2011. Data sekunder dikumpulkan dan dikelompokkan dalam bentuk tabel dan diagram. Kemudian data sekunder yang telah dikumpulkan diolah dahulu kemudian diambil kesimpulan.

\section{HASIL DAN PEMBAHASAN}

Berdasarkan hasil penelitian yang diambil dari data rekam medis penderita hipertensi rawat inap di RSUD Jombang periode Januari - Desember 2011 di dapatkan sebanyak 337 orang dengan diagnosa hipertensi. Dari sampel yang telah didapat tersebut kemudian di deskripsikan dalam bentuk tabel dan diagram.
Deskripsi Karakteristik Penderita Hipertensi Berdasarkan Usia

Data mengenai penderita hipertensi berdasarkan usia di RSUD Jombang periode Januari - Desember 2011 disajikan dalam bentuk tabel 1 .

Tabel 1. Deskripsi Karakteristik Penderita Hipertensi Berdasarkan Usia

\begin{tabular}{ccc}
\hline Usia & Frekuensi & Persentase $(\%)$ \\
\hline $21-30$ & 9 orang & $2,6 \%$ \\
$31-40$ & 21 orang & $6,4 \%$ \\
$41-50$ & 65 orang & $19,2 \%$ \\
$51-60$ & 112 orang & $33,3 \%$ \\
$=60$ & 130 orang & $38,5 \%$ \\
\hline Total & 337 orang & $100 \%$ \\
\hline
\end{tabular}

Berdasarkan tabel diatas menunjukkan bahwa dari 337 orang penderita hipertensi didapatkan klasifikasi usia terbanyak $>61$ tahun yaitu sejumlah 130 orang (38,5\%). Menurut Oktora (2007) dimana insiden hipertensi meningkat seiring pertambahan umur. Pernyataan tesebut sesuai Kumar (2005) yang menyatakan bertambahnya umur, maka tekanan darah juga akan meningkat. Setelah umur 45 tahun, dinding arteri akan mengalami penebalan oleh karena adanya penumpukan zat kolagen pada lapisan otot, sehingga pembuluh darah akan berangsur-angsur menyempit dan menjadi kaku. Tekanan darah sistolik meningkat karena kelenturan pembuluh darah besar yang berkurang pada penambahan umur sampai dekade ketujuh sedangkan tekanan darah diastolik meningkat sampai dekade kelima dan keenam kemudian menetap atau cenderung menurun.

Peningkatan umur akan menyebabkan beberapa perubahan fisiologis, pada usia lanjut terjadi peningkatan resistensi perifer dan aktivitas simpatik. Pengaturan tekanan darah yaitu refleks baroreseptor pada usia lanjut sensitivitasnya sudah berkurang, sedangkan peran ginjal juga sudah berkurang dimana aliran darah ginjal dan laju filtrasi glomerulus menurun.

\section{Deskripsi Karakteristik Penderita Hipertensi Berdasarkan Jenis Kelamin}

Data mengenai penderita hipertensi berdasarkan jenis kelamin di RSUD Jombang periode Januari - Desember 2011 disajikan dalam bentuk tabel 2 .

Tabel 2. Deskripsi Karakteristik Penderita Hipertensi Berdasarkan Jenis Kelamin

\begin{tabular}{ccc}
\hline Jenis Kelamin & Frekuensi & Persentase (\%) \\
\hline Laki-laki & 160 orang & $47,4 \%$ \\
Perempuan & 177 orang & $52,6 \%$ \\
& & \\
\hline Total & 337 orang & $100 \%$ \\
\hline
\end{tabular}

Tabel 2 menunjukkan bahwa dari 337 orang penderita hipertensi didapatkan klasifikasi jenis kelamin terbanyak adalah perempuan yaitu berjumlah 177 orang (52,6\%). Menurut Julius (2008) bahwa pada perempuan risiko hipertensi akan meningkat setelah masa menopouse yang mempengaruhi penurunan hormon estrogen yang menyebabkan penurunan kadar High Density Lipoprotein (HDL). Kadar kolesterol HDL yang rendah merupakan 
faktor penyebab dalam terjadinya proses aterosklerosis. Pada premenopause wanita mulai kehilangan sedikit demi sedikit hormon estrogen yang selama ini melindungi pembuluh darah dari kerusakan. Proses ini terus berlanjut dimana hormon estrogen tersebut berubah kuantitasnya sesuai dengan umur wanita secara alami, yang umumnya mulai terjadi pada wanita umur 45-55 tahun.

Laporan dari Sugiri di Jawa Tengah didapatkan angka prevalensi $6 \%$ pada laki-laki dan $11,6 \%$ pada perempuan. Daerah perkotaan Semarang 7,5\% pada laki-laki dan 10,9\% pada perempuan. Wade (2003) mengatakan, dimana di atas usia 50 tahun hipertensi lebih banyak terjadi pada wanita. Sedangkan pada laki-laki mempunyai risiko lebih tinggi untuk menderita hipertensi pada usia muda.

\section{Deskripsi Karakteristik Penderita Hipertensi Berdasarkan Tingkat Pendidikan}

Data mengenai penderita hipertensi berdasarkan tingkat pendidikan di RSUD Jombang periode Januari - Desember 2011 disajikan dalam bentuk tabel 3 .

Tabel 3. Deskripsi Karakteristik Penderita Hipertensi Berdasarkan Tingkat Pendidikan

\begin{tabular}{ccc}
\hline Pendidikan & Frekuensi & Persentase $(\%)$ \\
\hline SD & 159 orang & $47,2 \%$ \\
SMP & 44 orang & $13,1 \%$ \\
SMA & 62 orang & $18,3 \%$ \\
D3 & 11 orang & $3,3 \%$ \\
S1 & 61 orang & $18,1 \%$ \\
\hline Total & 337 orang & $100 \%$ \\
\hline
\end{tabular}

Berdasarkan hasil penelitian diketahui bahwa dari 337 penderita hipertensi yang menjalani rawat inap di RSUD Jombang pada tahun 2011, tingkat pendidikan terbanyak adalah SD dengan jumlah 159 orang $(47,2 \%)$. Menurut Notoatmodjo (2010) mengatakan bahwa tingkat pendidikan seseorang mempengaruhi kemampuan seseorang dalam menerima informasi dan mengolahnya sebelum menjadi perilaku yang baik atau buruk sehingga berdampak terhadap status kesehatannya. Pengetahuan individu mempengaruhi kesadaran terhadap perilaku pencegahan hipertensi, dengan kata lain makin tinggi pengetahuan individu mengenai penyebab hipertensi, faktor pemicu, tanda gejala, dan tekanan darah normal dan tidak normal maka individu akan cenderung menghindari hal hal yang dapat memicu terjadinya hipertensi, seperti perilaku merokok, minum kopi, dan obesitas.

\section{Deskripsi Karakteristik Penderita Hipertensi Berdasarkan Jenis Pekerjaan}

Data mengenai penderita hipertensi berdasarkan jenis pekerjaan di RSUD Jombang periode Januari - Desember 2011 disajikan dalam bentuk tabel 4 .
Tabel 4. Deskripsi Karakteristik Penderita Hipertensi Berdasarkan Jenis Pekerjaan

\begin{tabular}{ccc}
\hline Pekerjaan & Frekuensi & Persentase $(\%)$ \\
\hline Bidan & 2 orang & $0,6 \%$ \\
Ibu rumah tangga & 125 orang & $37,1 \%$ \\
Kuli bangunan & 8 orang & $2,4 \%$ \\
Mahasiswa & 2 orang & $0,6 \%$ \\
Makelar & 4 orang & $1,2 \%$ \\
Pedagang & 24 orang & $7,1 \%$ \\
Pensiunan guru & 3 orang & $0,9 \%$ \\
Pensiunan PNS & 39 orang & $11,6 \%$ \\
Petani & 37 orang & $10,8 \%$ \\
PNS & 43 orang & $12,8 \%$ \\
Serabutan & 5 orang & $1,5 \%$ \\
Supir & 2 orang & $0,6 \%$ \\
Tidak bekerja & 43 orang & $12,8 \%$ \\
\hline Total & 337 orang & $100 \%$ \\
\hline
\end{tabular}

Berdasarkan hasil penelitian diketahui bahwa dari 337 penderita hipertensi yang menjalani rawat inap di RSUD Jombang pada tahun 2011, jenis pekerjaan terbanyak adalah sebagai ibu rumah tangga dengan jumlah 125 orang $(37,1 \%)$. Hal ini berhubungan dengan faktor stress. Santoso (2010) menyatakan bahwa situasi stress seperti masalah pekerjaan, krisis keuangan, atau masalah keluarga dapat menaikkan tekanan darah.

\section{Deskripsi Karakteristik Penderita Hipertensi Berdasarkan Keluhan Utama}

Data mengenai penderita hipertensi berdasarkan keluhan utama di RSUD Jombang periode Januari Desember 2011 disajikan dalam bentuk tabel 5 .

Tabel 5. Deskripsi Karakteristik Penderita Hipertensi Berdasarkan Keluhan Utama

\begin{tabular}{ccc}
\hline Keluhan utama & Frekuensi & Persentase $(\%)$ \\
\hline Diare & 4 orang & $1,2 \%$ \\
Kaki bengkak & 4 orang & $1,4 \%$ \\
Mual dan muntah & 35 orang & $10,4 \%$ \\
Nyeri dada & 74 orang & $21,9 \%$ \\
Nyeri pinggang & 8 orang & $2,4 \%$ \\
Penglihatan kabur & 30 orang & $8,9 \%$ \\
Sakit kepala & 81 orang & $24,1 \%$ \\
Sesak nafas & 101 orang & $29,9 \%$ \\
Total & 337 orang & $100 \%$
\end{tabular}

Berdasarkan hasil penelitian diketahui bahwa dari 337 penderita hipertensi yang menjalani rawat inap di RSUD Jombang pada tahun 2011, didapatkan penderita dengan keluhan utama terbanyak adalah sesak nafas dengan jumlah 101 orang $(29,9 \%)$. Hal ini sesuai dengan pernyataan Susalit (2001) yaitu sesak nafas adalah hal yang sering dikeluhkan oleh sebagian besar penderita hipertensi, terutama yang hipertensinya berat atau menahun dan tidak diobati.

Pada penderita hipertensi, tahanan perifer sistemik menjadi lebih tinggi dari orang normal akibat adanya vasokontriksi pembuluh darah. Itu berarti ventrikel kiri harus bekerja lebih keras untuk melawan tahanan tersebut agar aliran darah maksimal sehingga suplai darah ke semua jaringan tercapai sesuai kebutuhannya. Ventrikel kiri kemudian mengompensasi keadaan tersebut dengan hipertrofi sel-sel otot jantung. Hipertrofi ventrikel kiri (left ventricle byperthropy, 
LVH) memungkinkan jantung berkontraksi lebih kuat dan mempertahankan volume sekuncup walaupun terjadi tahanan terhadap aliran darah. Namun, lama kelamaan mekanisme kompensasi tersebut tidak lagi mampu mengimbangi tekanan perifer yang tetap tinggi. Kegagalan mekanisme kompensasi menyebabkan penurunan kontraktilitas ventrikel kiri. Penurunan kontraktilitas ventrikel kiri akan diikuti oleh penurunan curah jantung yang selanjutnya menyebabkan penurunan tekanan darah. Semua hal tersebut akan merangsang mekanisme kompensasi neurohormonal seperti pengaktifan sistem saraf simpatis dan sistem RAA (reninangiotensin-aldosteron) (Silbernagl, 2007).

Pengaktifan sistem saraf simpatis akan meningkatkan kontraktilitas jantung hingga mendekati normal. Hal itu terjadi karena saraf simpatis mengeluarkan neurotransmiter (norepinefrin-NE) yang meningkatkan permeabilitas Ca2+ membran. Hal tersebut meningkatkan influks $\mathrm{Ca} 2+$ dan memperkuat partisipasi $\mathrm{Ca} 2+$ dalam proses kontraksi sel. Selain itu, stimulasi simpatis juga menyebabkan vasokontriksi perifer yang bertujuan mencegah penurunan tekanan darah lebih lanjut. Di sisi lain, penurunan curah jantung menyebabkan penurunan perfusi jaringan organ tubuh lainnya. Salah satunya adalah ginjal. Penurunan perfusi darah ke ginjal merangsang ginjal untuk menurunkan filtrasi dan meningkatkan reabsorbsi. Peningkatan reabsorbsi inilah yang menyebabkan kencing penderita berkurang dan peningkatan kadar serum ureum $(65 \mathrm{mg} / \mathrm{dl})$ di mana harga rujukannya sebesar $10-50 \mathrm{mg} / \mathrm{dl}$. Walaupun terjadi penurunan filtrasi glomerulus, dalam keadaan mantap stabil laju filtrasi kreatinin sama dengan laju ekskresinya. Hal inilah yang menyebabkan kadar kreatinin serum penderita sebesar 1,4 mg/dl masih mendekati batas normal (normal 0,6-1,3 mg/dl). Kedua hal di atas menunjukkan adanya penurunan fungsi ginjal.

Penurunan perfusi ginjal juga merangsang sel-sel juxtaglomerulus untuk mensekresi renin. Kemudian renin menghidrolisis angiotensinogen menjadi angiotensin I yang selanjutnya oleh angiotensin converting ensyme (ACE) akan diubah menjadi angiotensin II. Angiotensin II kemudian ditangkap oleh reseptornya di pembuluh darah (vascular ATR1) dan terjadi vasokontriksi. Bila angiotensin II diterima oleh reseptor sel korteks adrenal (adrenal ATR1) maka korteks adrenal akan mensekresi aldosteron. Aldosteron kemudian diikat oleh reseptornya di ginjal. Proses tersebut membuka $\mathrm{ENaC}$ (epithelial $\mathrm{Na}$ Channel) yang menyebabkan peningkatan retensi $\mathrm{Na}+$. Karena $\mathrm{Na}+$ bersifat retensi osmotik, peningkatan $\mathrm{Na}+$ akan diikuti peningkatan $\mathrm{H} 2 \mathrm{O}$. Hasil akhir semua proses tersebut adalah peningkatan aliran darah balik ke jantung akibat adanya peningkatan volume intravaskuler (Silbernagl, 2007).

Pada stadium awal gagal jantung, semua mekanisme kompensasi neurohormonal tersebut memang bermanfaat. Akan tetapi, pada stadium lanjut, mekanisme tersebut justru semakin memperparah gagal jantung yang terjadi dan dapat menyebabkan gagal jantung tak terkompensasi. Setelah terpajan dalam jangka waktu yang lama, jantung menjadi kurang tanggap terhadap NE. Akhirnya kontraktilitas jantung kembali menurun. Kedua, aktivitas simpatis dan RAA tetap terjadi. Akibatnya vasokontriksi, retensi cairan, peningkatan preload, dan peningkatan afterload tetap terjadi. Sel-sel ventrikel semakin terenggang dan kekuatan kontraksinya semakin menurun. Ventrikel kiri semakin tidak mampu memompa darah ke sistemik. Darah menjadi terbendung di atrium kiri menyebabkan hipertrofi atrium kiri (left atrium byperthropy, LAH) sebagai mekanisme kompensasi. Hipertrofi ventrikel akan menggeser letak musculus papillaris sehingga dapat terjadi regurgitasi mitral fungsional (terdengar sebagai bising pansistolik di apex yang menjalar ke lateral). Hal itu semakin memperberat kerja jantung dan penanda adanya pembesaran jantung (kardiomegali) selain ditunjukkan oleh ictus cordis yang bergeser ke lateral bawah dan batas jantung kiri bergeser ke lateral bawah serta foto thorax CTR 0,60. Lama kelamaan akan terjadi kongesti di vena pulmonalis.

Tekanan intravaskuler vena pulmonalis yang semakin tinggi menyebabkan cairan terdorong keluar dan terjadilah edema paru. Edema paru menyebabkan pasien sering merasa sesak napas saat beraktivitas ringan dan berbaring sebagai kompensasi akibat lumen bronkus dan alveolus mengecil yang menyebabkan pertukaran gas terganggu. Mungkin itu menjadi salah satu penyebab pasien sukar tidur. Pada edema paru, alveolus yang tergenang cairan transudasi yang menimbulkan suara ronki basah basal halus saat auskultasi. Di sisi lain, jaringan sistemik semakin kekurangan $\mathrm{O} 2$ dan proses metabolisme pun berubah menjadi metabolisme anaerob. Akibatnya terjadi peningkatan produksi asam laktat yang menyebabkan asidosis metabolik. Selain itu, pada gagal jantung kiri asidosis metabolik disebabkan oleh oksigenasi arteri berkurang dan peningkatan pembentukan asam di dalam darah akibat adanya penurunan pertukaran $\mathrm{O} 2$ dan CO2 di dalam alveolus paru. Peningkatan ion hidrogen $[\mathrm{H}+]$ merangsang kemoreseptor sentral sehingga terjadi hiperventilasi (Silbernagl, 2007).

\section{Deskripsi Karakteristik Penderita Hipertensi Berdasarkan Jenis Hipertensi}

Data mengenai penderita hipertensi berdasarkan jenis hipertensi di RSUD Jombang periode Januari - Desember 2011 disajikan dalam bentuk tabel 6.

Tabel 6. Deskripsi Karakteristik Penderita Hipertensi Berdasarkan Jenis Hipertensi

\begin{tabular}{ccc}
\hline Jenis Hipertensi & Frekuensi & $\begin{array}{c}\text { Persentas } \\
\text { e }(\%)\end{array}$ \\
Hipertensi primer & $\begin{array}{c}324 \text { orang } \\
96,2 \%\end{array}$ \\
Hipertensi sekunder & 13 orang & $3,8 \%$ \\
Total & 337 orang & $100 \%$
\end{tabular}

Berdasarkan hasil penelitian diketahui bahwa dari 337 penderita hipertensi yang menjalani rawat inap di RSUD Jombang pada tahun 2011, didapatkan penderita dengan hipertensi primer sebanyak 324 orang (96,2\%). Menurut Kowalski (2010) Hipertensi esensial merupakan 95\% dari seluruh kasus hipertensi. Sisanya adalah hipertensi sekunder. Glomerulonefritis, gagal ginjal, Hiperaldosteronisme, atau Sindrom Cushing merupakan penyakit yang dapat menyebabkan hipertensi. 
Deskripsi Karakteristik Penderita Hipertensi Berdasarkan Derajat Hipertensi

Data mengenai penderita hipertensi berdasarkan derajat hipertensi di RSUD Jombang periode Januari - Desember 2011 disajikan dalam bentuk tabel 4.7 dan gambar 7 .

Tabel 7. Deskripsi Karakteristik Penderita Hipertensi Berdasarkan Derajat Hipertensi

\begin{tabular}{ccc}
\hline Jenis Hipertensi & Frekuensi & $\begin{array}{c}\text { Persentas } \\
\text { e }(\%)\end{array}$ \\
Hipertensi primer & 324 orang & $96,2 \%$ \\
Hipertensi sekunder & 13 orang & $3,8 \%$ \\
Total & 337 orang & $100 \%$
\end{tabular}

Berdasarkan hasil penelitian diketahui bahwa dari 337 penderita hipertensi yang menjalani rawat inap di RSUD Jombang pada tahun 2011, didapatkan hipertensi derajat 2 merupakan kejadian terbanyak dengan jumlah 181 orang (53,8\%). Menurut Anggraini (2009) penderita hipertensi yang tekanan darahnya tinggi adalah penderita hipertensi yang telah berusia tua dan memiliki masalah pada jantungnya.

\section{Deskripsi Karakteristik Penderita Hipertensi Berdasarkan Riwayat Keluarga dengan Hipertensi}

Data mengenai penderita hipertensi berdasarkan riwayat keluarga dengan hipertensi di RSUD Jombang periode Januari - Desember 2011 disajikan dalam bentuk tabel 4.8 dan gambar 8 .

\section{Tabel 8. Deskripsi Karakteristik Penderita Hipertensi Berdasarkan Riwayat Keluarga}

$\begin{array}{ccc}\text { Riwayat Keluarga } & \text { Frekuensi } & \begin{array}{c}\text { Persentase } \\ (\%)\end{array} \\ \text { Ada } & 82 \text { orang } & 24,4 \% \\ \text { Tidak ada } & 255 \text { orang } & 75,6 \% \\ \text { Total } & 337 \text { orang } & 100 \%\end{array}$

Berdasarkan hasil penelitian diketahui bahwa dari 337 penderita hipertensi yang menjalani rawat inap di RSUD Jombang pada tahun 2011, didapatkan penderita hipertensi yang tidak ada riwayat keluarga dengan hipertensi 255 orang $(75,6 \%)$. Hal ini bertentangan dengan pernyataan Wade (2003), adanya faktor genetik pada keluarga tertentu akan menyebabkan keluarga itu mempunyai risiko menderita hipertensi. Hal ini berhubungan dengan peningkatan kadar sodium intraseluler dan rendahnya rasio antara potasium terhadap sodium Individu dengan orang tua dengan hipertensi mempunyai risiko dua kali lebih besar untuk menderita hipertensi dari pada orang yang tidak mempunyai keluarga dengan riwayat hipertensi.

\section{SIMPULAN}

Berdasarkan penelitian yang telah dilakukan, maka dapat ditarik kesimpulan bahwa dari 337 orang penderita hipertensi, jumlah terbanyak berumur? 61 tahun $(38,5 \%)$, berjenis kelamin perempuan $(52,6 \%)$, tingkat pendidikan
SD $(47,2 \%)$, pekerjaan ibu rumah tangga $(37,1 \%)$, keluhan utama sesak napas $(29,9 \%)$, hipertensi primer $(96,2 \%)$, hipertensi derajat $2(53,8 \%)$, tidak ada riwayat penyakit hipertensi pada keluarganya $(75,6 \%)$.

\section{DAFTAR PUSTAKA}

Anggraini, D.A, dkk. 2009, Faktor-Faktor yang Berhubungan dengan Kejadian Hipertensi pada Pasien yang Berobat di Poliklinik Dewasa Puskesmas Bangkinang Periode Januari Sampai Juni 2008.

Depkes RI, 2001, Survei Kesehatan Rumah Tangga tahun 2001. Jakarta: Departement Kesehatan RI.

Julius, S., 2008, Clinical Implications of Pathophysiologic Changes in the Midlife Hypertensive Patients. American Heart Journal, 122: 886-891.

Kowalski, R., 2010, Terapi Hipertensi. Terjemahan: Rani S. Bandung: Qanita Zulkeflie, NASB 2011

Kumar V, Abbas AK, Fausto N. Pathologic basic of disease. 7th ed. Philadelphia: Elsavier Saunders, pp 270-5.

Notoadmodjo, 2010, Promosi Kesehatan dan Ilmu Perilaku. Jakarta: Rineka Cipta.

Oktora R., 2007, Gambaran Penderita Hipertensi Yang Dirawat Inap di Bagian Penyakit Dalam RSUD Arifin Achmad Pekanbaru Periode Januari Sampai Desember 2005, Skripsi, FK UNRI, hal 41-42.

Santoso, D., 2010, Membonsai Hipertensi. Surabaya: Temprina Medika Grafika.

Sarastini, N., 2008, Faktor-faktor yang berhubungan dengan kejadian hipertensi pada masyarakat usia 30 tahun keatas depok tahun 2008. Journal of hypertension factor research, 21 (2), 1-8, doi : 486/nejmoa 3291/full.

Silbernagl, S. 2007. In: Silbernagl, S., Lang, F. editor. Teks dan Atlas Berwarna Patofisiologi. Jakarta : EGC

Susalit, 2001, Buku Ajar Penyakit Dalam, Jakarta :Balai Penerbit FKUI.

Wade, A Hwheir, D N Cameron, A., 2003, Using a Problem Detection Study (PDS) to Identify and Compare Health Care Privider and Consumer Views of Antibypertensive therapy. Journal of Human Hypertension, Jun Vol 17 Issue 6,p397

World Health Organization (WHO), 2005, Risk Factor. Available from : http://www.who.int/cardiovascular_ diseases/en/cvd_atlas_03_risk_factors.p df. 